Journal of Sustainable Development of Transport and Logistics

journal home page: https://jsdtl.sciview.net

Azemsha, S., Yasinskaya, V., \& Hryshchanka, T. (2020). Sustainable development in Belarus: Goals for transport and safety indicator movements. Journal of Sustainable Development of Transport and Logistics, 5(1), 19-27. doi:10.14254/jsdtl.2020.5-1.2.

\title{
Sustainable development in Belarus: Goals for transport and safety indicator movements
}

\author{
Siarhei Azemsha *iD, Volha Yasinskaya **, Tatsiana Hryshchanka *** \\ * Department of Road Transport and Traffic Management, Belarusian State University of Transport, \\ 34, Kirova street, Gomel, 246653, Republic of Belarus \\ s-azemsha@yandex.ru \\ ${ }^{*}$ Department of Road Transport and Traffic Management, Belarusian State University of Transport, \\ 34, Kirova street, Gomel, 246653, Republic of Belarus \\ iasola@gmail.com \\ ${ }^{* * *}$ Department of Road Transport and Traffic Management, Belarusian State University of Transport, \\ 34, Kirova street, Gomel, 246653, Republic of Belarus \\ 6475455@gmail.com
}

\section{open $(2$ access (c) do}

Article history:

Received: January 05, 2020

1st Revision: February 12,

2020

Accepted: April 07, 2020

\section{DOI:}

10.14254/jsdtl.2020.5-1.2

\begin{abstract}
The purpose of this article is to formulate and structure the many goals of the 2030 Agenda for Sustainable Development related to transport and to review the dynamics of changes in indicators of achievement in the Republic of Belarus of those related to safety. The article used methods of collecting and analyzing information with statistical tools using specialized software. The main results are the formation of the many Sustainable Development Goals (SDGs) of the 2030 Agenda related to transport and their structuring. Statistical models have also been obtained showing the dynamics of changes in SDGs related to safety. The study shows how the application of methods of analysis, structuring and statistical data processing can assess the reachability of SDG and, thereby, establish the main places of application of efforts to achieve SDG for transport.
\end{abstract}

Keywords: sustainable development goals, sustainable mobility, universal access, efficiency, safety, green mobility.

\section{Introduction}

On September 25, 2015, UN member states adopted the 2030 Agenda for Sustainable Development. It contains 17 SDGs aimed at eliminating poverty, conserving planetary resources and ensuring well-being for all. Republic of Belarus took an active part in the development of the 2030 Agenda at all its stages and committed itself to achieving the SDG. So, in order to formulate a clear mechanism for implementing the 2030 Agenda and implement overall coordination of activities to achieve SDG in Belarus, the post of National Coordinator for achieving the Sustainable Development

Corresponding author: Siarhei Azemsha

E-mail: s-azemsha@yandex.ru

This open access article is distributed under a Creative Commons Attribution (CC-BY) 4.0 license. 
Goals has been established. Under his leadership, formed: Council for Sustainable Development, which included representatives of government bodies and organizations at the level of deputy leaders; Parliamentary Group on SDG; Regional SDGs; Partner Group for Sustainable Development. The Secretariat of the National Coordinator and the Sustainable Development Council is the Ministry of Foreign Affairs. The management architecture for achieving SDG in Belarus is shown in Figure 1.

\section{Figure 1: Management structure for achieving SDG in the Republic of Belarus}

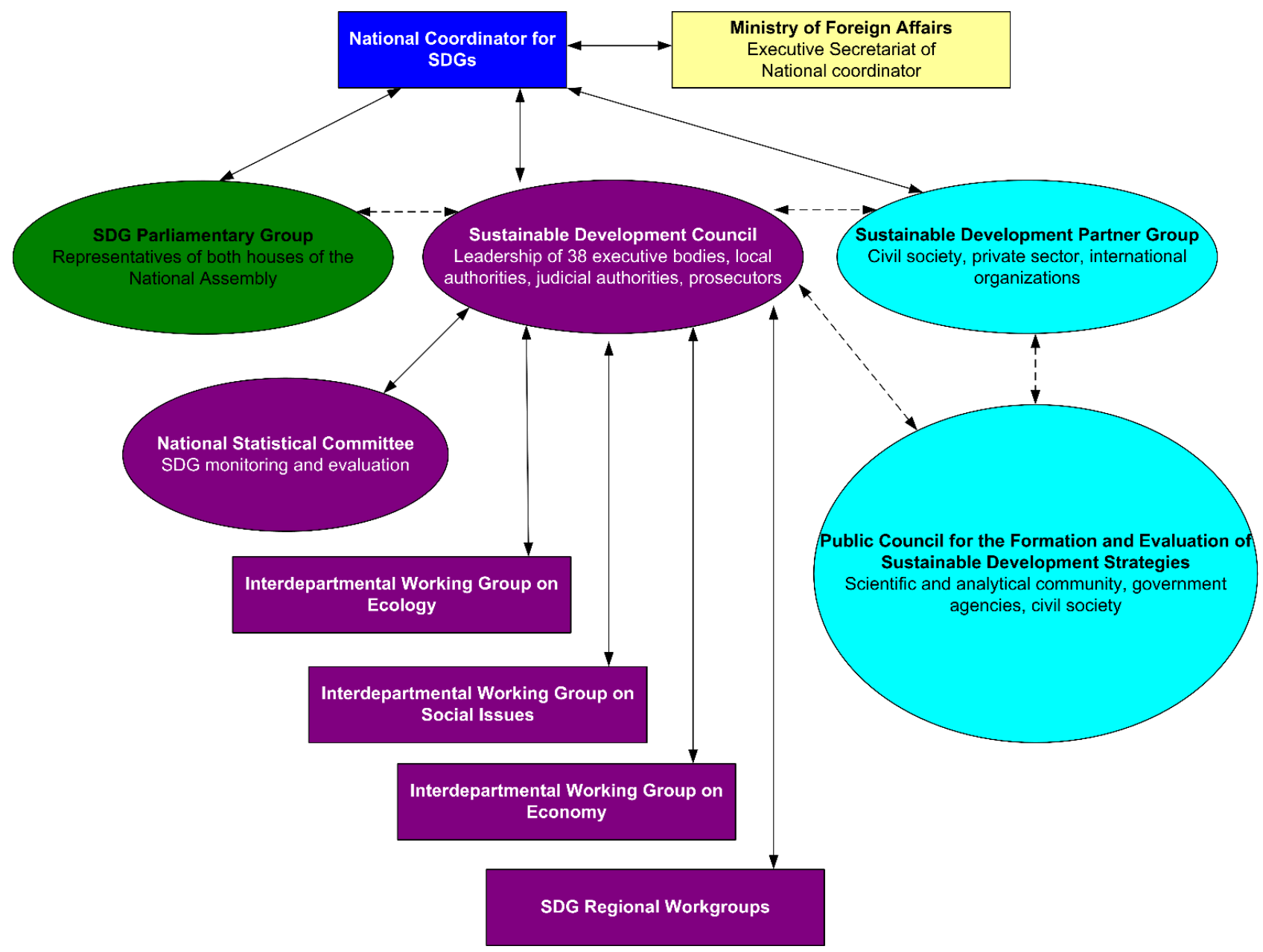

Source: Ministry of Foreign Affairs of the Republic of Belarus (2017)

Two SDG targets are directly transport-related. Target 3.6: By 2020 to halve the number of global deaths and injuries from road traffic accidents. Target 11. 2: Aims to, by 2030, provide access to safe, affordable, accessible and sustainable transport systems for all, improving road safety, notably by expanding public transport, with special attention to the needs of those in vulnerable situations women, children, persons with disabilities and older persons. Transport is a field of activity that concerns almost every citizen, and therefore a number of SDGs depend on the quality of its functioning. The structuring of such goals, as well as the development of scientific tools for their attainability and its application for the Republic of Belarus is a problem field for this study.

\section{Literature review}

In the 2030 Agenda for Sustainable Development, sustainable transport is mainstreamed across several SDGs and targets, especially those related to food security, health, energy, economic growth, infrastructure, and cities and human settlements. The importance of transport for climate action is further recognized under the UNFCCC - the transport sector will be playing a particularly important role in the achievement of the Paris Agreement, given the fact close to a quarter of energy-related global greenhouse gas emissions come from transport and that these emissions are projected to grow 
substantially in the years to come. The importance of transport in achieving the sustainable development goals is also emphasized in the resolutions of the UN General Assembly (A/RES/69/213 Role of transport and transit corridors in ensuring international cooperation for sustainable development and A/RES/72/212 - Strengthening the links between all modes of transport to achieve the Sustainable Development Goals). In 2014, United Nations Secretary-General Ban Ki-moon appointed an independent High-Level Advisory Group on Sustainable Transport to provide a focused set of recommendations on how the transport sector can advance sustainable development with poverty eradication at its core, promote economic growth, and bolster the fight against climate change. The outcome of this effort is Mobilizing Sustainable Transport for Development, the first ever Global Sustainable Transport Outlook Report, addressing all modes of transport, in developing and developed countries (United Nations, 2016). Obviously, a new analysis of the work of transport in achieving the SDGs will be given based on the results of 5 May 2020 - Second United Nations Global Sustainable Transport Conference in Beijing, China (United Nations, 2020). (Fig. 2):

It should be noted that all SDGs related to transport are conventionally divided into 4 groups

- safety;

- universal access;

- efficiency;

- green mobility.

Figure 2: Accepted classification of transport related SDGs

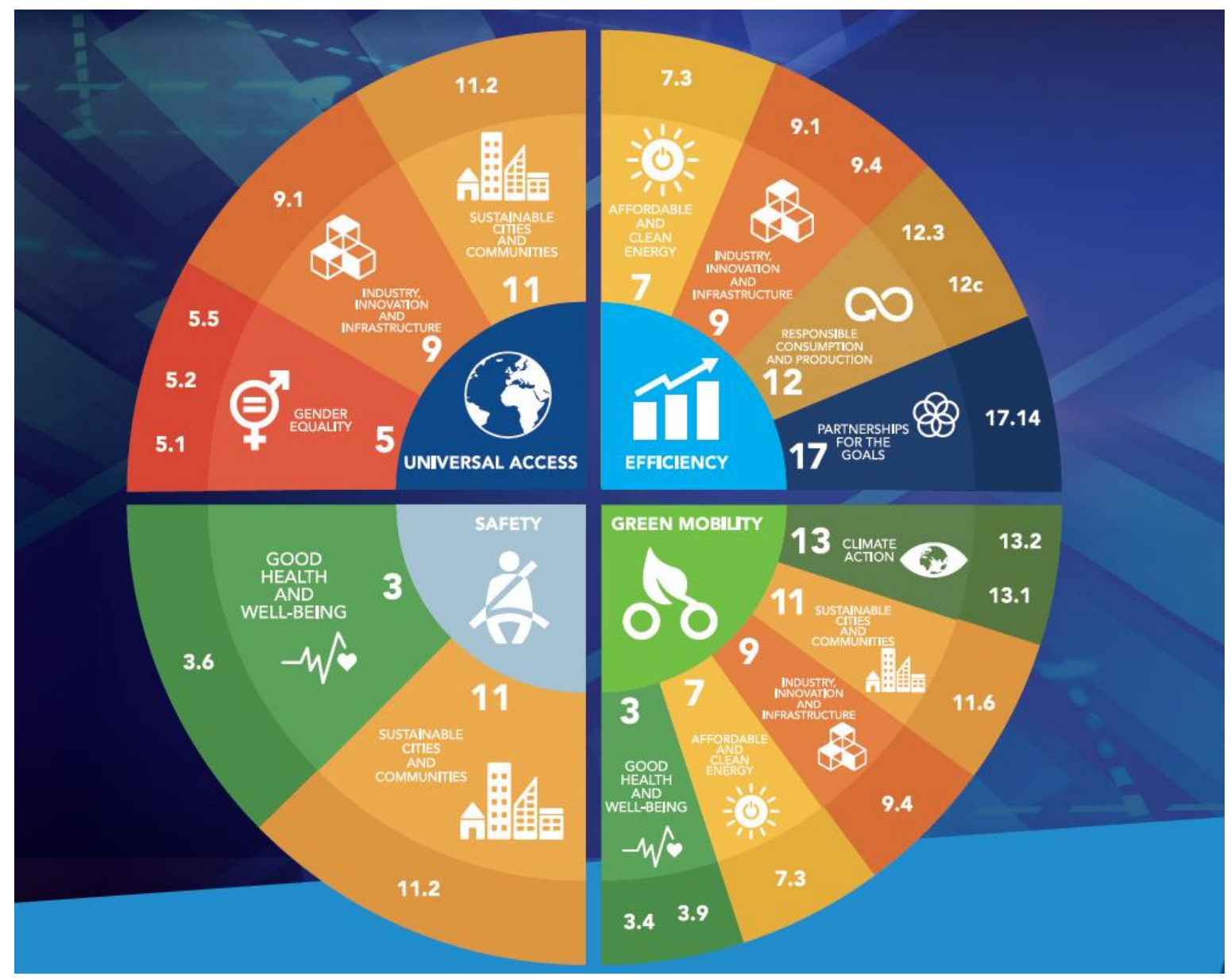

Source: Sustainable Mobility for All. (n.d.)

There are other ways to group targets for transport (Figure 3, 4). 
Figure 3: UNECE sustainable transport division contribution sustainable SDGs

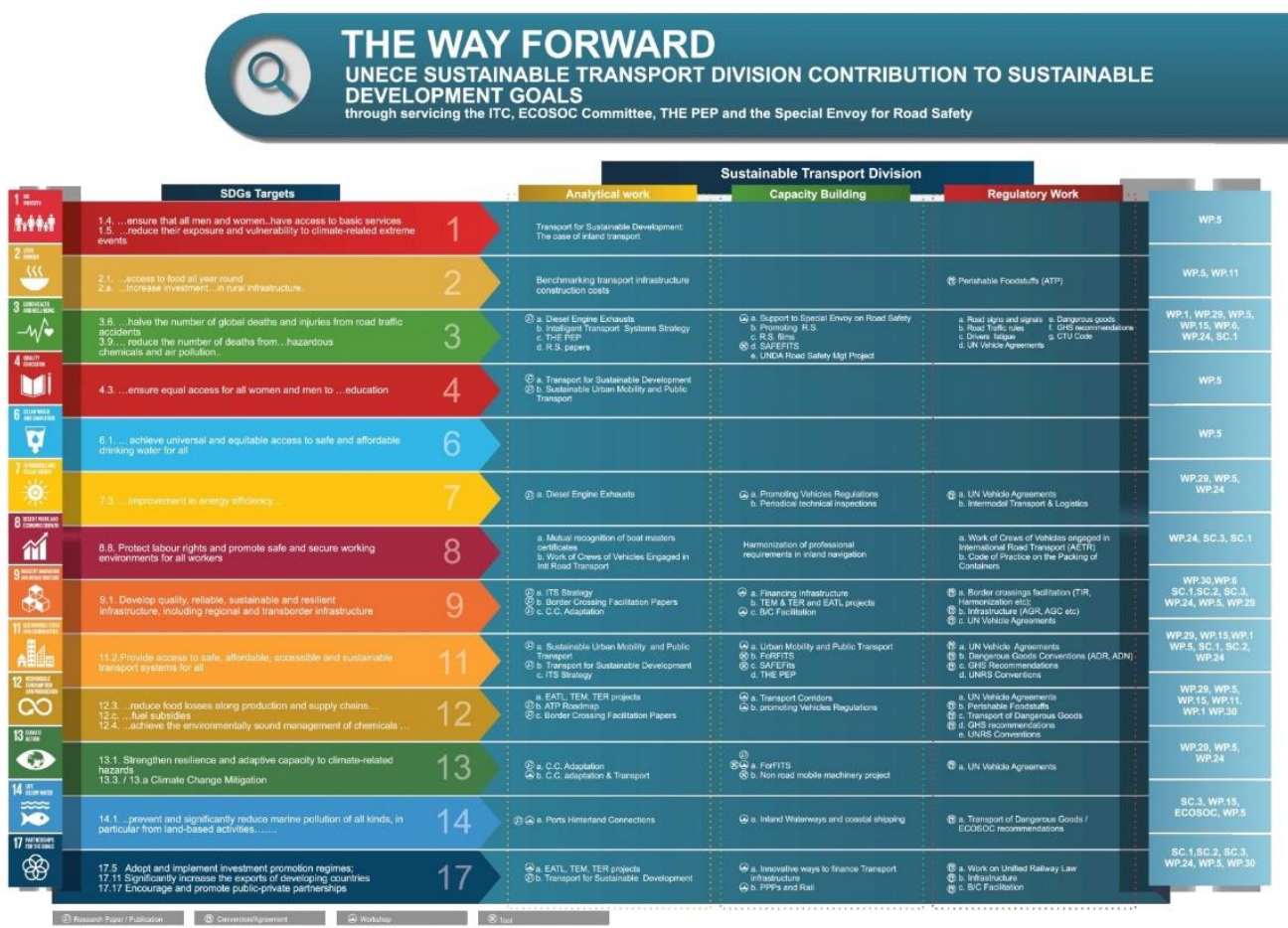

Source: UNECE. (n.d. a)

Figure 4: UN Transport Conventions, under UNECE ITC purview, and the SDGs

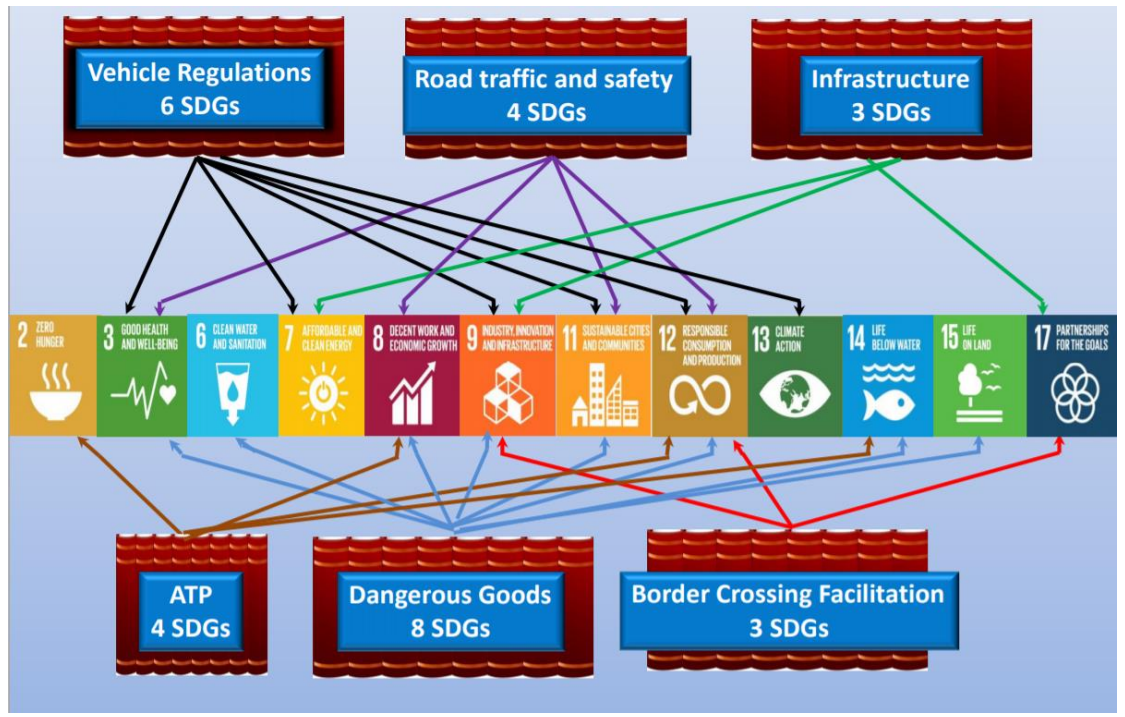

Source: UNECE. (n.d. b)

Proximity to the beginning of Second United Nations Global Sustainable Transport Conference determines the need to summarize certain results of the work done. Realization of the need to perform such surveys on the example of the Republic of Belarus was the motive for this study.

\section{Research methods}

The article used methods of collecting and analyzing information. In particular an analysis of the goals and objectives shown in Figure 2 shows that a number of SDGs and the tasks shown in this figure will not be related to transport. So, it seems obvious that tasks 5.1, 5.2, 5.512 .3 and 13.2 (see Fig. 2) are unlikely to have any relation to transport. This is due to the very formulation of the goal, as well as the name of the tasks for these goals, as well as an indicator that measures the achievement of the task. 
So, for example, task 5.1 sounds like this: "End all forms of discrimination against all women and girls everywhere." The indicator evaluating progress in solving this problem is: "Whether or not legal frameworks are in place to promote, enforce and monitor equality and non-discrimination on the basis of sex". Obviously, such a task is related to standard-setting (legal) activity, and not to transport.

At the same time, it seems that a number of sustainable development tasks, not reflected in Figure 2, are related to transport. These tasks include:

- 8.4: "Improve progressively, through 2030, global resource efficiency in consumption and production and endeavor to decouple economic growth from environmental degradation, in accordance with the 10-year framework of programs on sustainable consumption and production, with developed countries taking the lead"

- 12.2: "By 2030, achieve the sustainable management and efficient use of natural resources."

The indicators for assessing progress on both of these tasks are the same and they are:

- Material footprint, material footprint per capita, and material footprint per GDP;

- Domestic material consumption, domestic material consumption per capita, and domestic material consumption per GDP.

It seems obvious that the qualitative characteristics of the transport system directly affect resource consumption, as well as material consumption. Therefore, it is proposed to add them to the SDG task list in two groups: efficiency and green mobility.

Also in the article, methods of statistical analysis of data were used. In particular, to assess the dynamics of SDGs indicators 3.6.1. «Death rate due to road traffic injuries» and 11.2.1. «Proportion of population that has convenient access to public transport, by sex, age and persons with disabilities» linear and non-linear regression analysis implemented in [8] was used.

\section{Research results}

Given the analysis of the collected information, Figure 2 will take the form shown in Fig. 5.

Figure 5: Suggested classification of SDGs

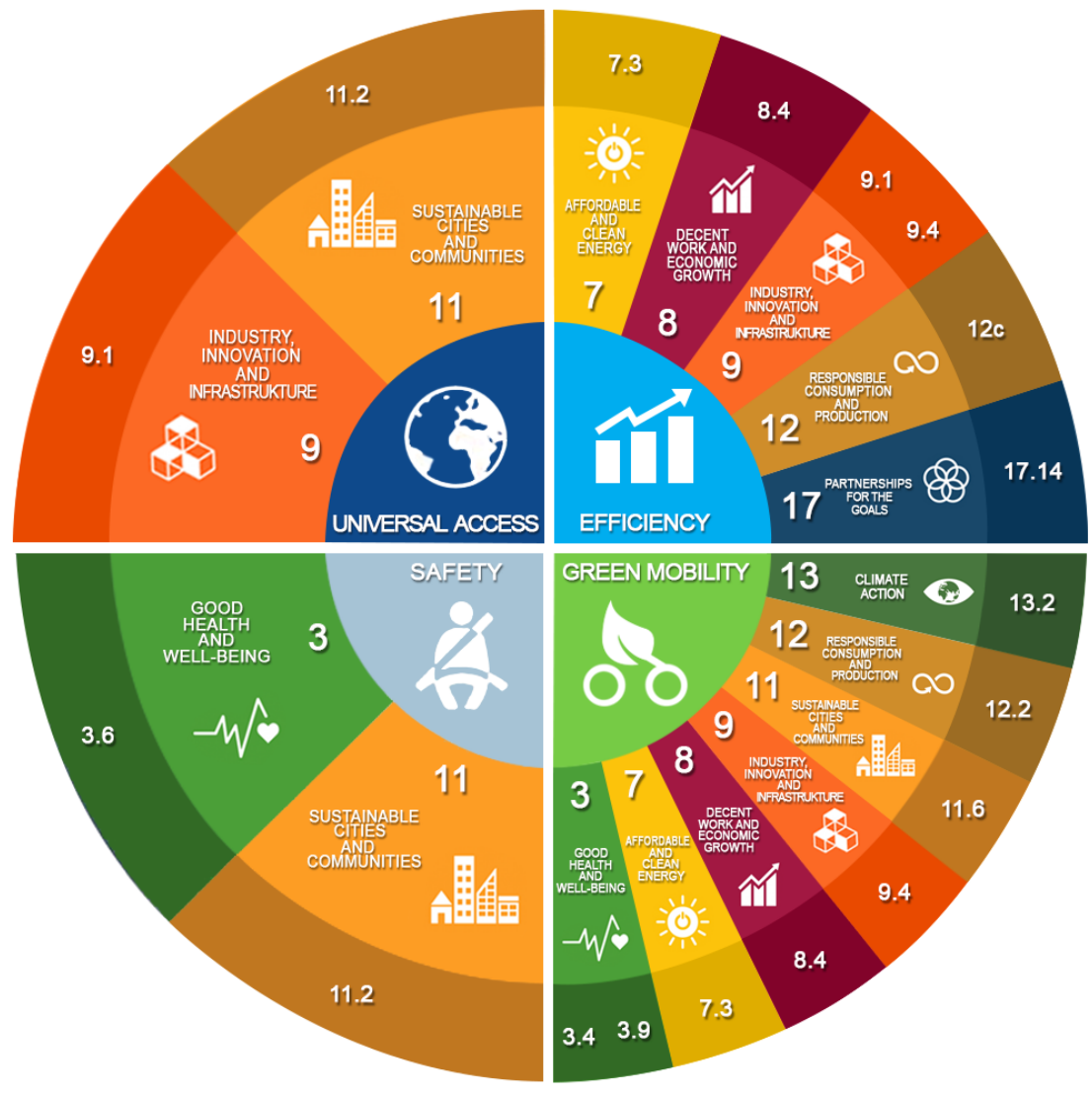


It seems logical that safety-related tasks are paramount. These include (see Fig. 5) tasks 3.6 and 11.2. Their name, as well as indicators that evaluate the dynamics of their changes, are shown in Table 1.

Table 1: SDGs indicators related to transport to the block "safety"

\begin{tabular}{lccc} 
Name SDG & The name of the task & $\begin{array}{c}\text { Global indicator of } \\
\text { SDG }\end{array}$ & $\begin{array}{c}\text { Republic of Belarus } \\
\text { indicator of SDG }\end{array}$ \\
\hline
\end{tabular}

Goal 3: Ensure 3.6 «By 2020, halve the number of global 3.6.1. «Death rate due to 3.6.1. «Death rate due to healthy lives and deaths and injuries from road traffic road traffic injuries» road traffic injuries» promote well- accidents»

being for all at all

ages

Goal 11: Make 11.2 «By 2030, provide access to safe, 11.2.1. «Proportion of 11.2.1. «Proportion of cities and human affordable, accessible and sustainable population that has population that has settlements transport systems for all, improving road convenient access to convenient access to inclusive, resilient safe, safety, notably by expanding public public transport, by sex, public transport, by sex, sustainable and transport, with special attention to the age and persons with age and persons with needs of those in vulnerable situations, disabilities» disabilities» women, children, persons with disabilities and older persons»

Source: Sustainable Mobility for All (n.d.).

The following is an analysis of the dynamics of changes in these indicators in the Republic of Belarus.

Indicator 3.6.1. «Death rate due to road traffic injuries» - the number of deaths in road accidents per year per 100,000 population. The dynamics of this indicator are shown in Figure 6.

Figure 6: Dynamics of changes in indicator 3.6.1 "Death rate due to road traffic injuries", regression lines and forecast values for 2020

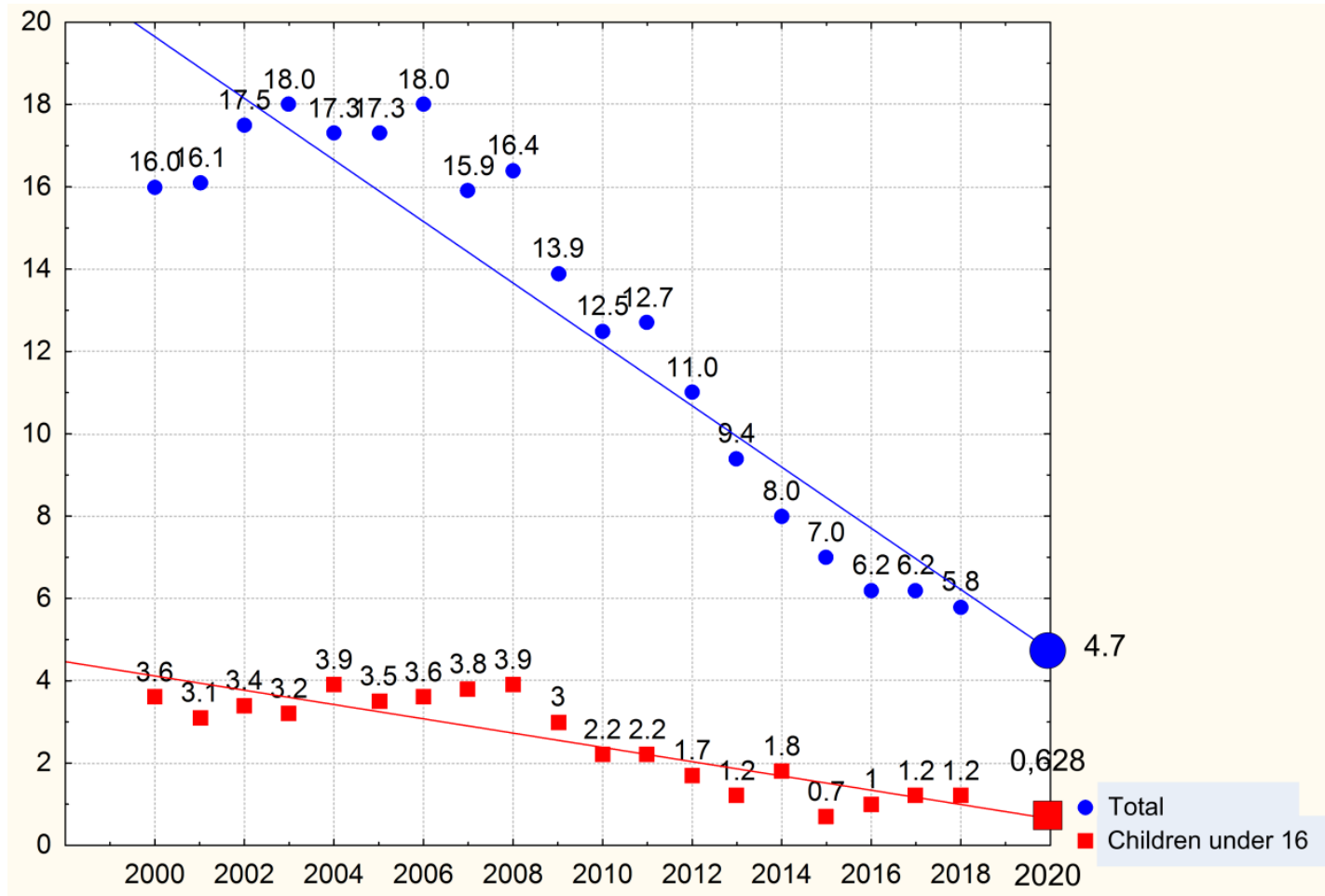

Source: National Statistical Committee of the Republic of Belarus (2018) 
Figure 6 also shows the regression models that allow to obtain the predicted values of mortality due to road accidents for 2020 equal to:

- 4.7 deaths per 100,000 of the population in total for the Republic of Belarus;

- 0.628 dead children under the age of 16 per 100,000 of the population.

The regression models obtained using (National Statistical Committee of the Republic of Belarus, (2017) have the form:

- $\mathrm{N}=11414.39-1499.13 \operatorname{Ln}(\mathrm{x})$ - for the entire population of the Republic of Belarus (correlation coefficient 0.93 , determination coefficient 0.86 , significance level less than 0.05 );

- $\mathrm{N}_{16}=351.116-0.1735 \mathrm{x}$ - for children under the age of 16 (correlation coefficient 0.87, determination coefficient 0.75 , significance level less than 0.05 ).

Given that the task is formulated as follows: «By 2020, halve the number of global deaths and injuries from road traffic accidents » and it was formulated in 2015 , when the values $\mathrm{N}=7$, a $\mathrm{N}_{16}=0.7$, then the targets for 2020 will be equal $N=3.5$, a $N_{16}=0.35$. Substituting the values of 2020 in the above regression models, we can obtain:

- $\mathrm{N}=11414.39-1499.13 \operatorname{Ln}(2020)=4.73$;

$-\mathrm{N}_{16}=351.116-0.17352020=0.646$.

Thus, while maintaining the inertial development scenario, the set target mortality rates in road accidents for 2020 will not be realized.

Indicator 11.2.1. "Proportion of population that has convenient access to public transport, by sex, age and persons with disabilities" - the proportion of the population whose travel time by foot from home to the nearest public transport stop takes no more than 15 minutes, in the total population, in percent. The dynamics of its change is shown in Fig. 7.

Figure 7: Dynamics of changes in the share of the population with convenient access to public transport

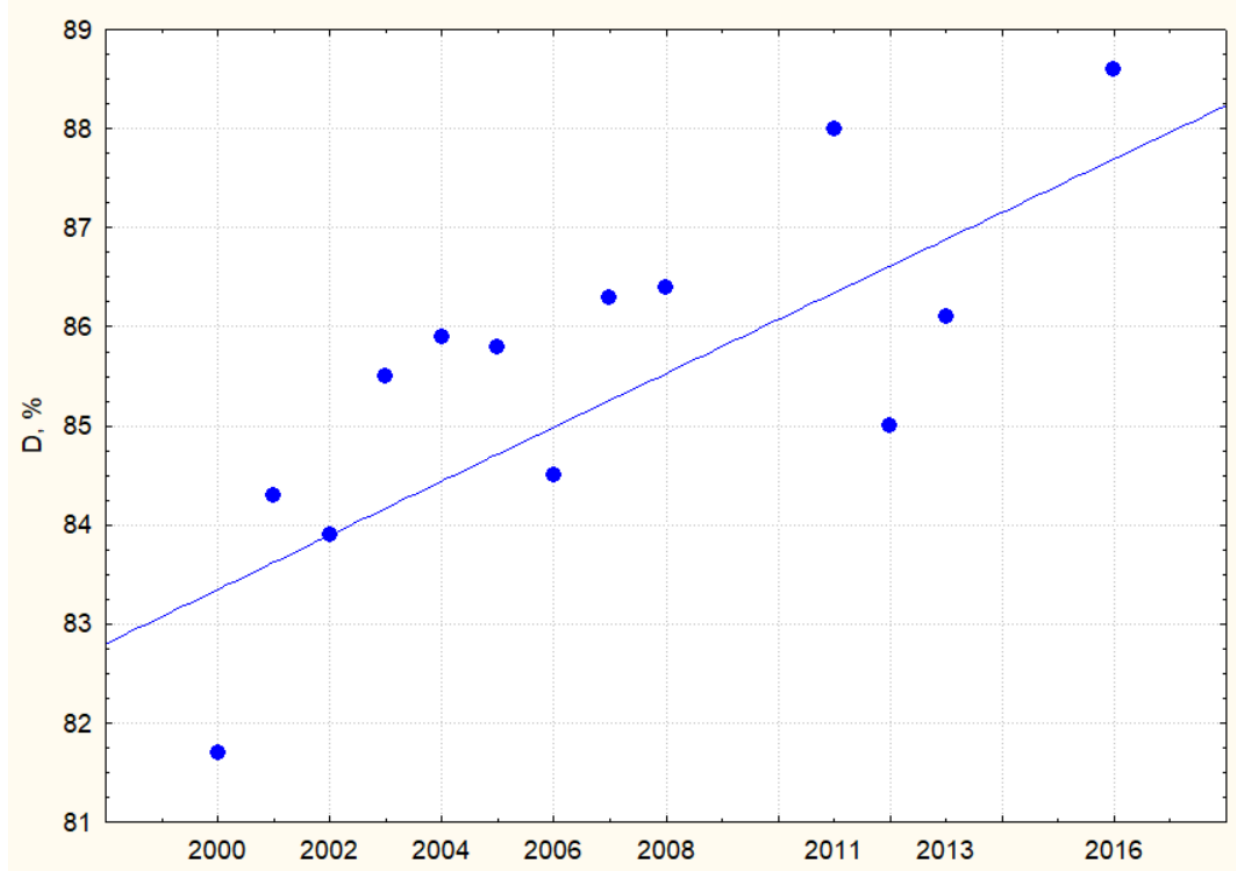

Fig. 7 also shows the regression model, which allows to obtain the predicted values of Indicator 11.2.1. The regression model obtained using Statistica has the form: $D=631-1095310 /$ Year (correlation coefficient 0.77, determination coefficient 0.59, significance level less than 0.05). Substituting D $=100 \%$ into the regression equation, we can obtain that full coverage of the population with convenient access to public transport will be achieved by 2063 . 


\section{Discussion of the results}

The above classification of SDGs related to transport into 4 categories seems to be very successful. It allows structuring the list of all SDGs, which in turn allows to more flexibly manage them.

Using regression analysis to assess the reachability of SDGs also seems successful. This will allow us to assess the possibility of achieving (not achieving) the target values of SDGs and timely respond to possible delays.

\section{Conclusions}

Thus, this article shows the role of transport in achieving SDGs, as well as an assessment of the dynamics of changes in safety indicators in the Republic of Belarus. In particular, it was found that:

1. Dynamics of SDG 3.6.1 "Death rate due to road traffic injuries" has a downward trend. At the same time, the calculations show that while maintaining such a dynamics of decline, the stated goals will not be achieved on time.

2. Dynamics of SDG 11.2.1 indicator "Proportion of population that has convenient access to public transport, by sex, age and persons with disabilities" has a growing trend. At the same time, calculations show that while maintaining such a growth rate of $100 \%$, public transport coverage will not be achieved by 2030, but by 2063 .

It is obvious that in order to achieve the target values of the safety indicator in the Republic of Belarus, it is necessary to develop measures aimed at accelerating the decline of SDG 3.6.1 "Death rate due to road traffic injuries" and accelerating the growth of DG 11.2.1 "Proportion of population that has convenient access to public transport, by sex, age and persons with disabilities". Such events can be derived from generalized experience, for example (National Statistical Committee of the Republic of Belarus, 2017). However, the work of a consortium of a number of interested organizations from different countries under the auspices of an international project (Horizon2020, Erasmus+ and etc.) will be preferable.

\section{Citation information}

Azemsha, S., Yasinskaya, V., \& Hryshchanka, T. (2020). Sustainable development in Belarus: Goals for transport and safety indicator movements. Journal of Sustainable Development of Transport and Logistics, 5(1), 19-27. doi:10.14254/jsdtl.2020.5-1.2

\section{References}

Ministry of Foreign Affairs of the Republic of Belarus. (2017). Startovye pozicii Belarusi po dostizheniju Celej ustojchivogo razvitija [Starting positions of Belarus in achieving the Sustainable Development Goals]. Minsk: Riftour. Retrieved from http://mfa.gov.by/upload/GUMDI/SDG_start.pdf

National Statistical Committee of the Republic of Belarus. (2017). 11.2.1 Dolya naseleniya, imeyushchego udobnyy dostup $k$ obshchestvennomu transportu, $v$ razbivke po polu, vozrastu $i$ priznaku invalidnosti (protsent) [11.2.1 Percentage of population with convenient access to public transport, disaggregated by sex, age and disability (percentage)]. Retrieved from http://sdgplatform.belstat.gov.by/sites/belstatfront/index-info.html?indicator=11.2.1

National Statistical Committee of the Republic of Belarus. (2018). 3.6.1 Smertnost' v rezul'tate dorozhno-transportnykh proisshestviy (na 100000 chelovek naseleniya) [3.6.1 Mortality due to road traffic accidents (per 100,000 people)]. Retrieved from http://sdgplatform.belstat.gov.by/sites/belstatfront/index-info.html?indicator=3.6.1

Sustainable Mobility for All. (n.d.). Implementing the SDGs. Retrieved from https://sum4all.org/implementing-sdgs

Sustainable Mobility for All. (n.d.). Online tool toward sustainable mobility. Retrieved from http://www.sum4all.org/gra-tool/interactive-tool 
UNECE. (n.d.a). Transport and the Sustainable Development Goals. Retrieved from https://www.unece.org/mc/trans/transport-and-the-sdgs.html

UNECE. (n.d.b). SDGs and the UN Transport Conventions. Retrieved from https://www.unece.org/fileadmin/DAM/trans/conventn/UN_Transport_Agreements_and_Conve ntions.pdf

United Nations. (2016). Mobilizing Sustainable Transport for Development High-level Advisory Group on Sustainable Transport, by: High-level Advisory Group on Sustainable Transport. Retrieved from https://sustainabledevelopment.un.org/content/documents/2375Mobilizing\%20Sustainable\%2 0Transport.pdf

United Nations. (2020). Second United Nations Global Sustainable Transport Conference, Beijing, China. Retrieved from https://www.un.org/en/conferences/transport2020

Share - copy and redistribute the material in any medium or format Adapt - remix, transform, and build upon the material for any purpose, even commercially.

The licensor cannot revoke these freedoms as long as you follow the license terms.

Under the following terms:

Attribution - You must give appropriate credit, provide a link to the license, and indicate if changes were made.

You may do so in any reasonable manner, but not in any way that suggests the licensor endorses you or your use.

No additional restrictions

You may not apply legal terms or technological measures that legally restrict others from doing anything the license permits.

Journal of Sustainable Development of Transport and Logistics (ISSN: 2520-2979) is published by Scientific Publishing House "CSR", Poland, EU and Scientific Publishing House "SciView", Poland, EU

Publishing with JSDTL ensures:

- Immediate, universal access to your article on publication

- High visibility and discoverability via the JSDTL website

- Rapid publication

- Guaranteed legacy preservation of your article

- Discounts and waivers for authors in developing regions

Submit your manuscript to a JSDTL at https://jsdtl.sciview.net/ or submit.jsdtl@sciview.net 